\title{
Waste to Energy: An Assessment of Application of the Selective Fuel for Applications in Industries using a Mixture of " $A$ " Grade Coal and Municipal Solid Waste
}

\author{
Nripendra Bajracharya ${ }^{1}$, Bhakta Bahadur Ale ${ }^{2}$, Ramesh Man Singh ${ }^{3}$ and Tri Ratna Bajracharya ${ }^{4}$ \\ 1,2,4 Department of Mechanical Engineering, Pulchowk Campus, Institute of Engineering \\ Tribhuvan University, Kathmandu, Nepal \\ ${ }^{3}$ Center for Energy and Environment- Nepal, Kathmandu \\ Corresponding author:nri_bajra@ioe.edu.np, centre.energy@gmail.com, triratna@ioe.edu.np
}

Received: Feb. 20, 2016 Revised: July 9, 2016 Accepted:Aug. 1, 2016

\begin{abstract}
This paper is about how the garbage that is considered as nuisance can actually be a source of energy that is vital for us. The fuel prepared by blending combustible fraction of waste is called refuse derived fuel (RDF). When the waste is mixed with coal known as selective fuel, they can be the replacement for coal in industries. The vertical shaft brick kiln (VSBK) has been taken as a representative of industrial sector. This is the theme of this research. The coal sample used is from Assam, India which is the A grade coal normally used in VSBKs of Nepal. The selective fuel was undergone proximate analysis, smoke index test, flue gas emission test and was also tested for its calorific value. The moisture content and ash content is found to be $8.69 \%$ and $11.21 \%$ respectively which is the acceptable range for VSBK. The fixed carbon content of the fuel is $28.03 \%$. The sulphur content of the coal is $6.4 \%$ which can be captured using $\mathrm{Ca}(\mathrm{OH})_{2}$. Addition of lime and presence of excess air help to control smoke during combustion. Flue gas emission test shows $\mathrm{CO}$ emission of $56.66 \mathrm{ppm}, \mathrm{CO}_{2}$ emission of $2 \%$ and no $\mathrm{SO}_{2}$ emission. The economic analysis shows that installation of small scale briquetting plant is feasible. Besides this, mathematical calculation has also been done to deduce some results.
\end{abstract}

Key words: Briquette, calorific value, VSBK, municipal solid waste, coal.

\section{Introduction}

Waste to energy is a proven renewable energy technology that recovers energy from waste [7]. Energy recovery from waste is the conversion of mostly non-recyclable wastes into usable heat, electricity, or fuel through a variety of processes viz combustion, gasification, pyrolysis, anaerobic digestion, briquetting and landfill gas (LFG) recovery. This technique helps to reduce carbon emissions by offsetting the need for energy from fossil fuel as well as reduce methane generation from landfills [7].

For reducing the amounts of waste to be land-filled, alternate waste management activities such as composting, 3R (reduce, reuse, recycle) principle etc. should be applied. Among them, waste to 
energy conversion technique can be one of the plausible options. The waste to energy conversion can be an economical plus environment friendly approach for addressing the issue of waste management as well as the ongoing energy crisis. Among the Municipal Solid Waste, food waste, textile, rubber, leather, wood can be the source of elevated energy value and plastic bags can have the energy equivalent to that of kerosene [13]. Such materials of significance should not be dumped in the landfill and their energy content should be extracted for useful purpose. The heating values of Polyethylene and Polypropylene are over $41868 \mathrm{~kJ} / \mathrm{kg}$ and Polystyrene has values over 39774.6 $\mathrm{kJ} / \mathrm{kg}$ [2]. Due to their high calorific value and embodied energy, plastics are being incinerated solely or in combination with MSW in many developed countries [1]. In this context, the refuse derived fuel (RDF) and selective fuel (SF) briquettes can provide us with a cheap and renewable solution to both the problem of waste management and energy crisis at the same time. Since food waste has relatively low energy content, the heating value of MSW in the developing world tends to be lower than that of more industrialized countries [9]. The RDF (mixing paper, plastic and other combustible fraction) and the selective fuel (prepared by mixing Assam coal and combustible fraction of the municipal solid waste) can be used for industrial applications for example in brick kilns and cement factories.

In case of KMC, 18 percent of total budget of KMC is expended on solid waste management [12]. But sustainable management of the waste has not been achieved yet. The fuel briquette (selective fuel) formed by the combination of coal and combustible fraction of the waste helps to reduce the export of coal from India assisting in reduction of fossil fuel on one hand. On the other hand, it also helps to provide an alternate source of energy for ongoing energy shortage and an environment friendly mechanism for sustainability of waste management.

\section{Methodology}

This research is primarily based on quantitative analysis. The quantitative analysis consists of chemical experiments, calorific value analysis, proximate analysis etc. The paper is also based on analysis of secondary data. Economic analysis of the fuel is also being done. The research is conducted by using research tools like literature survey, experiments, statistical technique and laboratory equipments like furnace, oven, bomb calorimeter, mass balance.

The municipal solid waste were collected from Lalitpur and Kathmandu municipality's transfer stations via the mini-tata vehicle and brought to the test center. From these MSW, the combustible fractions like paper, plastic, cloth, rubber, leather, organic materials were sorted out to be used in the selective fuel. The waste was sun dried for 5 hours daily for 25 days. The other raw materials like coal, calcium hydroxide were also sun dried for 5 hours daily for 20 days. However, this much of sun drying may not be necessary. Depending upon the amount and moisture content of waste, the drying duration can be adjusted. The boulder form coal was broken into pieces using a hammer and then made into fine pieces using the grinding machine. Whereas the powdery form of coal were refined in the grinder directly. The plastic and paper waste were shredded with the help of shredding machine as far as possible and later made into finer pieces i.e. less than $5 \mathrm{~mm}$ in size. The clothes and rest of the paper and plastic were shredded manually using scissors and scale. The cutting and the drying process were carried out somewhat simultaneously. Those portions of the waste which do not serve as a source for fuel were discarded. For the laboratory tests, different types of samples were prepared on the basis of expected calorific value and composition of the materials. $\mathrm{Ca}(\mathrm{OH})_{2}$ is used in the briquette for capturing harmful emissions. The calculations shows that for $100 \mathrm{~g}$ of coal, $14.8 \mathrm{~g}$ of $\mathrm{Ca}(\mathrm{OH})_{2}$ is required. 


\subsection{Laboratory Works}

The calorific values of both the waste material and coal were determined to find out the mixing ratio to get the desired energy content from the mixture of different component. Since the coal and waste portions are selectively mixed with each other this fuel is named as selective fuel. This type of fuel is also named as eco-fuel in other literatures since they are supposed to be eco-friendly. The proximate analysis of waste as well as coal was carried out to determine the characteristics of the materials to match the suitability as a fuel. The laboratory works were mainly carried out in the lab of CEE-N and some variables were tested in the laboratory of NESS Pvt. Ltd. In the CEE-N the tests were performed under the supervision of the instructor. The production of briquette was done at laboratories of NAST and in CEE-N.

\section{Results and Discussions}

\subsection{Physical Characteristics}

The physical characteristics of one of the sample of selective fuel produced from the screw extruder machine is described as follows.

Table1: Physical description of a SF

\begin{tabular}{|c|c|}
\hline Parameters & Description \\
\hline Color & brownish \\
\hline Shape of briquette & Hollow cylindrical \\
\hline Outer diameter & $0.059 \mathrm{~m}$ \\
\hline Inner diameter & $0.023 \mathrm{~m}$ \\
\hline Length & $0.115 \mathrm{~m}$ \\
\hline Weight & $0.326 \mathrm{~kg}$ \\
\hline Density & $1225.563 \mathrm{~kg} / \mathrm{m}^{\wedge} 3$ \\
\hline
\end{tabular}

\subsection{Moisture Content}

Calorific Value decreases with the increase in moisture content of fuel. An acceptable percentage of external fuel moisture content should be between $5 \%$ and $10 \%$. Excessive moisture content results in poor combustion as well as energy losses [8]. 
132 Waste to Energy: An Assessment of Application of the Selective Fuel for Applications in Industries using .....

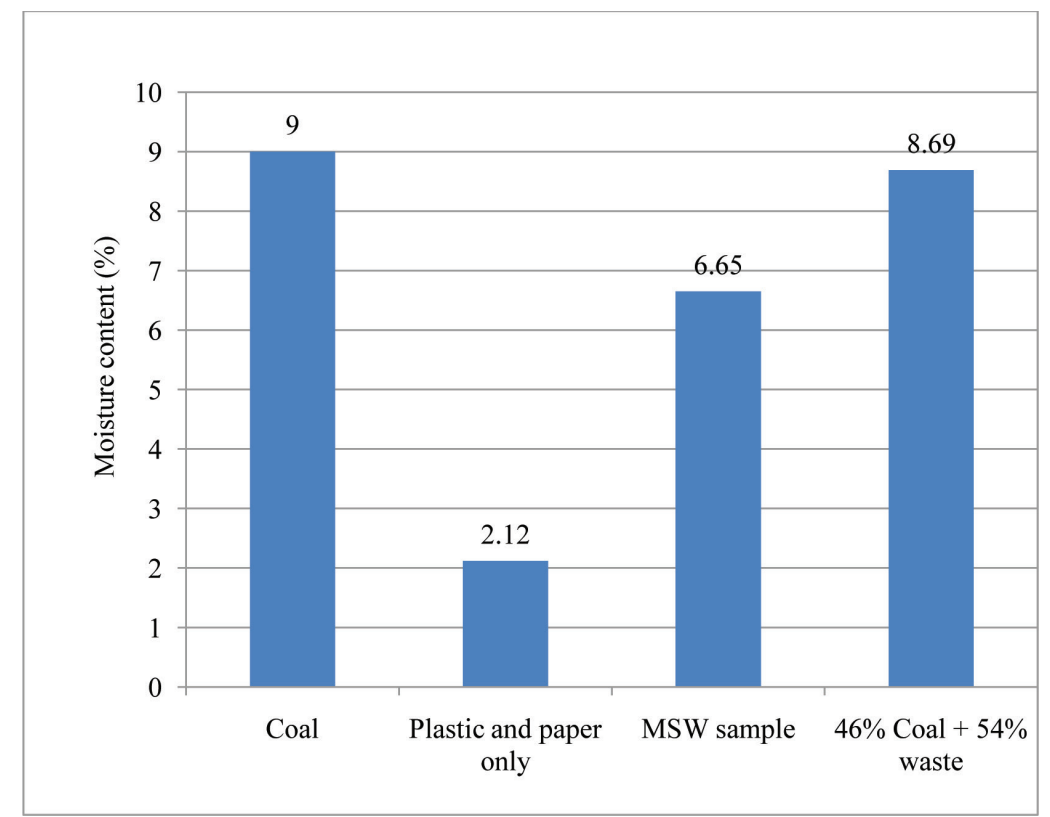

Fig. 1: Moisture content values of different samples

From the observation, it can be seen that the plastic waste has lower moisture content than both coal and overall MSW. When the coal is added to the waste its moisture content get increased. So if we consider solely the plastic waste only, it is helpful to increase calorific value of the mixture.

\subsection{Ash Content}

Higher ash content lowers the heating effect of the briquette as there is increment in the combustion remnant.

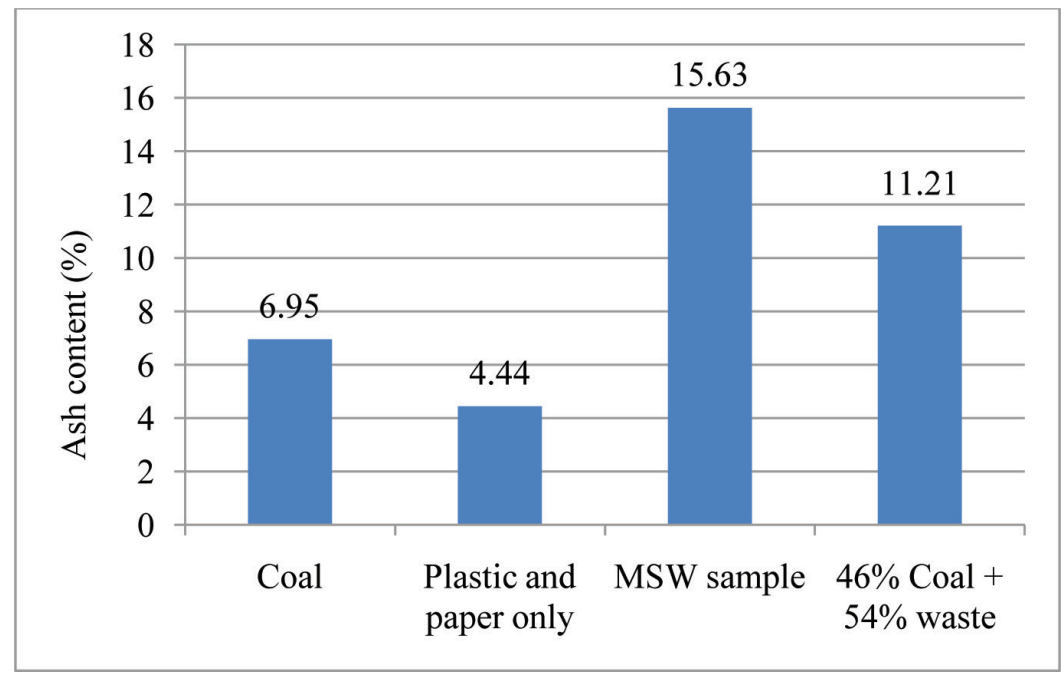

Fig. 2: Ash content of various samples 
From the graph, it can be seen that the plastic has lower ash content than the coal but the ash content increases when the MSW is considered as a whole. But the ash content gets lowered when MSW is mixed with coal as the ash contribution from the waste is reduced. In general the lower the ash content, the better the fuel becomes. For industrial purposes, a fuel having ash content from $10 \%$ to $25 \%$ should be used; fuel having ash content higher than $40 \%$ should be rejected [8].

\subsection{Volatile Matter Content}

The ignition rate will be low if the content of volatile matter is less. Hence high volatile matter enhances proper burning of the fuel [8]. The percentages of volatile matter in different sample are tabulated below.

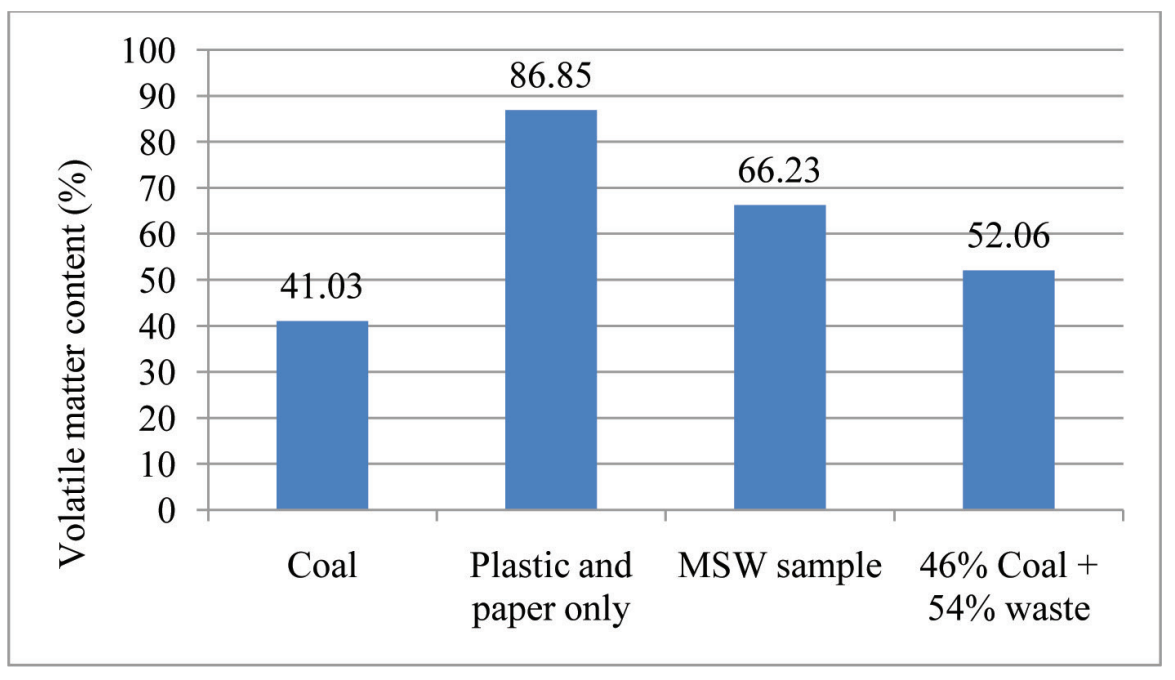

Fig. 3: Volatile matter content of different samples

From the graph, it can be seen that higher content of volatile matter in the plastic waste and MSW has profound effect on the selective fuel enhancing its ignition rate as the VM content of the mixture fuel get increased. The Volatile Matter in coal should be between $15 \%$ and $25 \%$; any coal having a higher content than $40 \%$ should be rejected. Coal with high volatile matter content burns with a long flame which is not desirable in a VSBK [8]. So, this factor need further research to find a solution to decrease the amount of volatile matter.

\subsection{Fixed Carbon Content}

Higher the fixed carbon contents of a fuel, longer will be the process of combustion. It is expected that the high percentage of fixed carbon and its smokeless flame will enhance the heat value and combustion duration of the briquette. 
134 Waste to Energy: An Assessment of Application of the Selective Fuel for Applications in Industries using .....

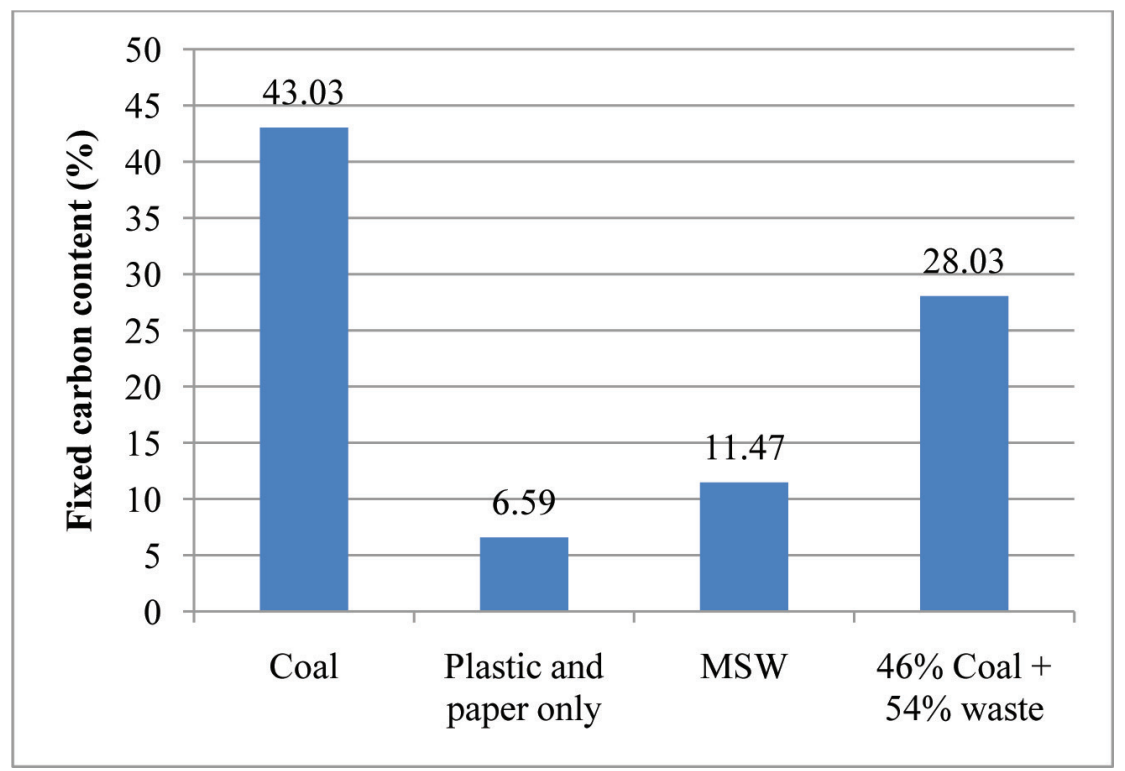

Fig. 4: Fixed carbon content of different samples

As seen in the graph, there is increment in the fixed carbon content of the fuel if the coal is added to the fuel. Higher Volatile matter content also decreases fixed carbon content. So, there must be a balance between fixed carbon content and volatile matter. But there is no fixed value of fixed carbon content that is best for VSBK. Higher the fixed carbon content, the better it is for VSBK.

\subsection{Sulphur Content}

The sulphur content in the coal is $6.4 \%$. The waste will have sulphur only in trace amount. A reasonable sulphur content of coal is between $0.5 \%$ and $1 \%$. Coal having Sulphur $>2 \%$ should not be used because higher content of sulphur causes sulphur dioxide $\left(\mathrm{SO}_{2}\right)$ pollution and it has a direct negative effect on the health of workers and damages vegetation, life-stock and human population in the surrounding area. So to capture sulphur, $\mathrm{Ca}(\mathrm{OH})_{2}$ has been used which prevent $\mathrm{SO}_{2}$ emissions. $\mathrm{CaO}$ and $\mathrm{CaCO}_{3}$ can also be used as the sulphur capturing agents but we used $\mathrm{Ca}(\mathrm{OH})_{2}$ as it is readily available from gas welding units. $\mathrm{Ca}(\mathrm{OH})_{2}$ can also be used to capture NOx emissions. Introduction of lime based desulfurizing agent such as $\mathrm{CaCO}_{3}$ and $\mathrm{Ca}(\mathrm{OH})_{2}$ into the briquettes can reduce the $\mathrm{SO}_{2}$ emissions by $80-90 \%$ thus minimizing the pollution [14].

\subsection{Calorific Value}

The calorific value of the coal should ideally be between $18,840.6$ to $23,027.4 \mathrm{~kJ} / \mathrm{kg}$. Coal having a CV of less than $14,653.8 \mathrm{~kJ} / \mathrm{kg}$ and more than $31,401 \mathrm{~kJ} / \mathrm{kg}$ should be rejected [8]. 


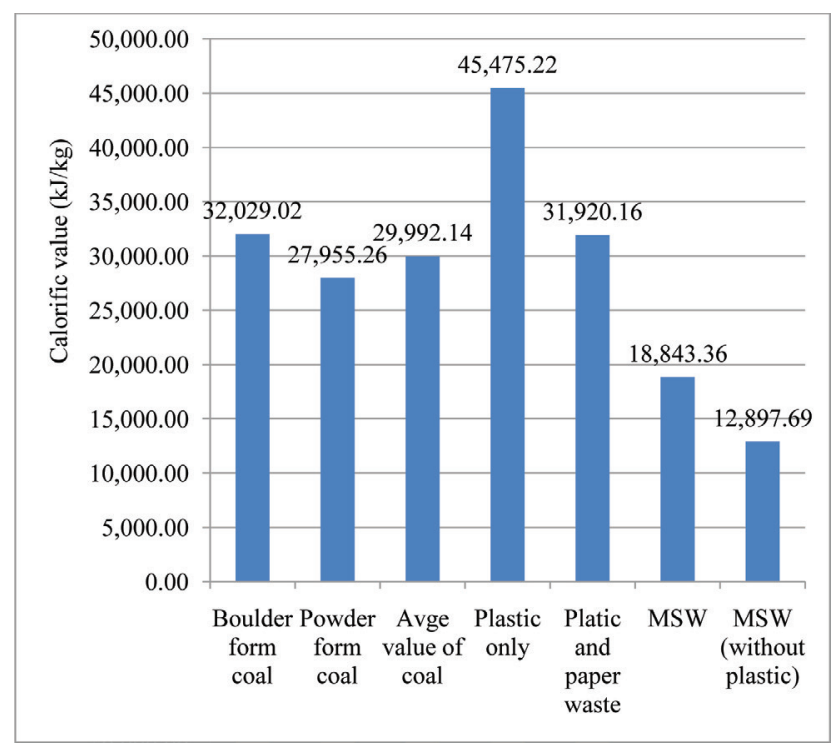

Fig. 5: Calorific values of different samples

From the tabular data above, it can be clearly seen that the boulder form coal has higher calorific value than powder form as powder form coal is contaminated with soil whereas the boulder form is in pure form and some even have luster. Plastic has calorific value of about $45475.22 \mathrm{~kJ} / \mathrm{kg}$, so it must not be thrown away as waste and another trend we can see in the waste stream is as the amount of plastic decreases, so does the calorific value of the waste sample. To determine the average value of coal, it has been assumed that both the boulder and powder form of coal are in equal proportion, so the average value of coal is $(27955.26+32029.02) / 2=29,992.14 \mathrm{~kJ} / \mathrm{kg}$. If calorific values of developed and developing countries are compared, it can be seen that the calorific values of Chinese MSW are typically less than half of those of the developed countries, which are mainly composed of sorted organic wastes [10].

\subsection{Role of Plastic in Increasing the Calorific Value}

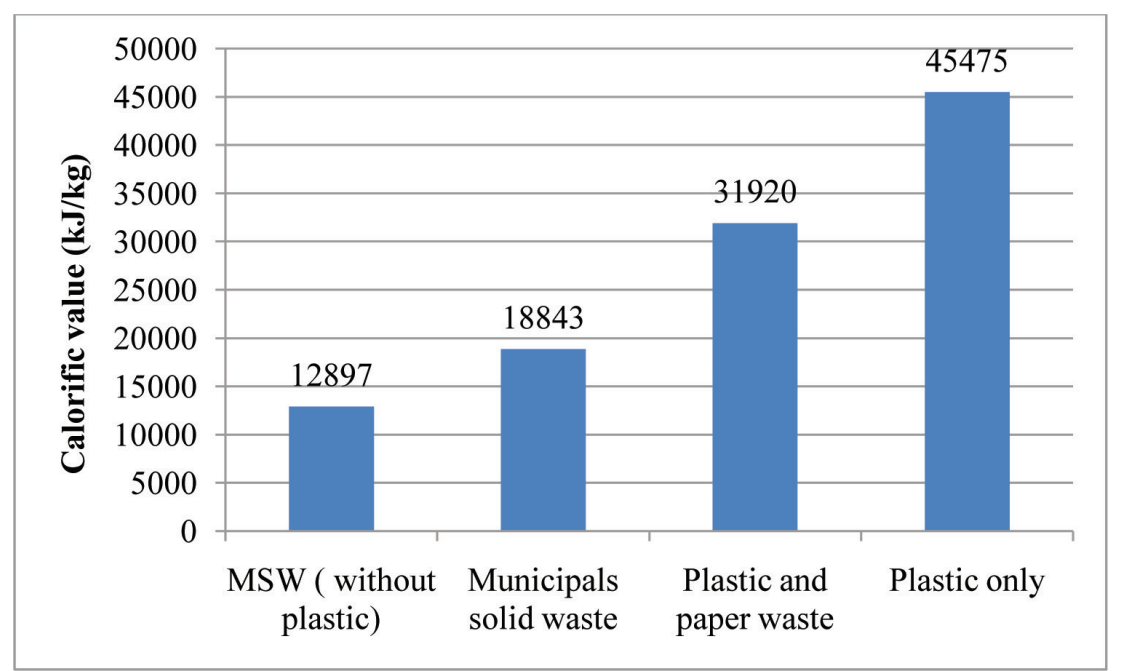

Fig. 6: Increasing calorific value with increasing content of plastic 
From left to right in the graph, it can be seen that as the plastic content in the material increases, its calorific value increases too. So these plastic wastes can be added to low grade coals like lignite coal which have calorific value around $12560.4 \mathrm{~kJ} / \mathrm{kg}$. The calorific value of lignite and polythene (PE) mixture has increased by nearly two folds by the introduction of $25 \% \mathrm{PE}$ in the lignite briquette [13].

\subsection{Role of plastic in the parameters of proximate analysis:}

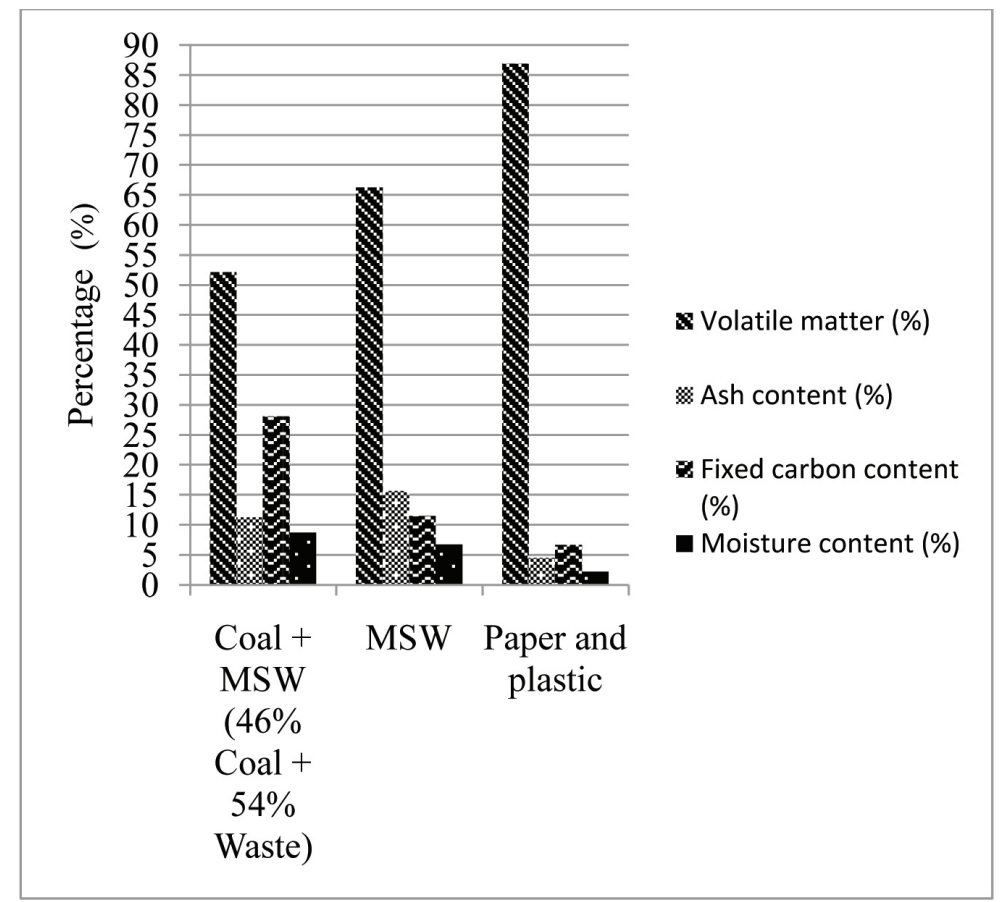

Fig. 7: Effect of plastic content in proximate behavior

From the graphical representation above, it can be concluded that as the percentage of plastic content increases (from left to right in the graph), there is increment in volatile matter and decrement in both fixed carbon and moisture content. However we cannot find specific correlation between plastic and ash content. Increment in plastic content also increases the breaking strength of the briquette and hence make it more durable [13].

\subsection{Thermal efficiency and other parameters}

Table 2: Efficiency and other parameters

\begin{tabular}{|l|l|l|l|l|}
\hline Briquette type & $\begin{array}{l}\text { Thermal } \\
\text { efficiency } \\
(\%)\end{array}$ & $\begin{array}{l}\text { Specific fuel con- } \\
\text { sumption }\end{array}$ & $\begin{array}{l}\text { W a t e r } \\
\text { evaporated } \\
(\mathrm{kg})\end{array}$ & $\begin{array}{l}\text { Maximum } \\
\text { Flame Temperature } \\
\left({ }^{\circ} \mathrm{C}\right)\end{array}$ \\
\hline $60 \%$ coal and $40 \%$ waste & 17.53 & 1.46 & 0.44 & $774.9^{\circ} \mathrm{C}$ \\
\hline
\end{tabular}


The thermal efficiency of the stove with the briquette as input fuel is found to be $17.53 \%$ and the fuel with calorific value of $23027.4 \mathrm{~kJ}$ is enough to be applicable in VSBK [8].

The following is the temperature profile during water boiling test that is obtained from the data logger. $\mathrm{T} 1$ is the flame temperature, $\mathrm{T} 2$ is the water temperature and $\mathrm{T} 1-\mathrm{T} 2$ compares the difference between those two temperatures.

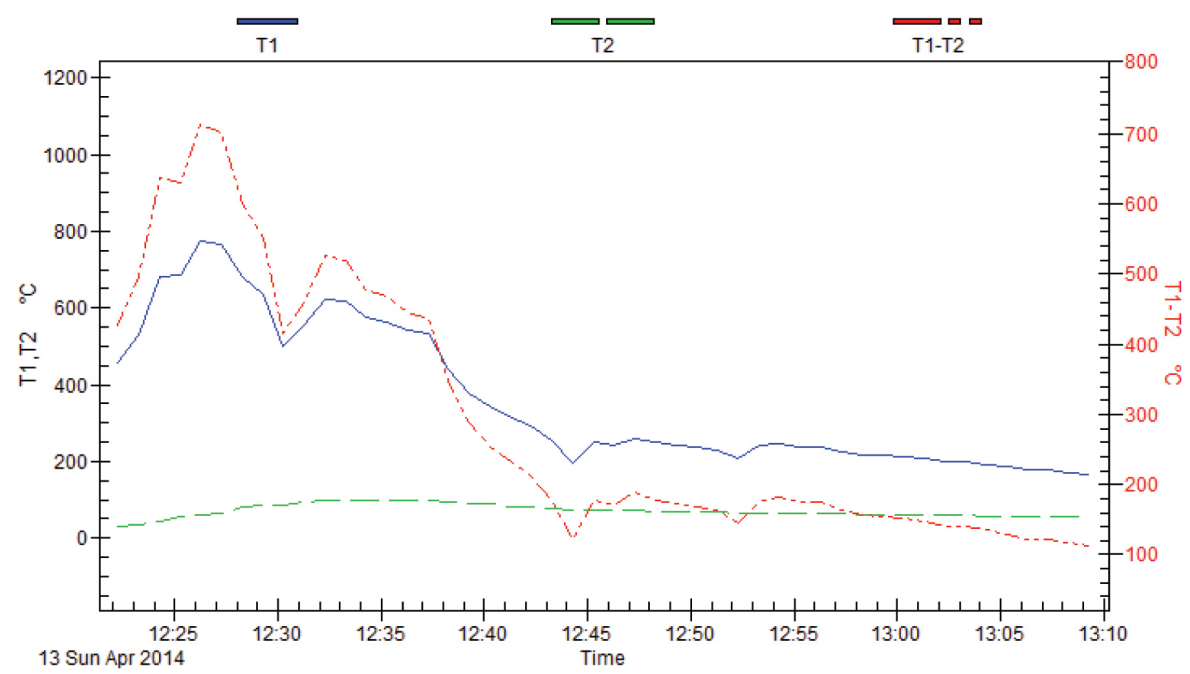

Fig 8: Temperature profile during water boiling test

\subsection{Smoke Index Test}

Table 3: Smoke index

\begin{tabular}{|l|l|l|}
\hline Sample & Result & Remarks \\
\hline Coal & 8 & With excess air \\
\hline Briquette without lime & $>7$ & Without excess air \\
\hline Briquette without lime & 3 & With excess air \\
\hline Briquette with lime & 4 & Without excess air \\
\hline Briquette with lime & 3 & With excess air \\
\hline
\end{tabular}

When the different sample of fuel is burnt, smoke trapped during combustion is compared with values of smoke testing scale. Bacharach oil burner smoke has a scale from 0 to 9 where 0 means no smoke and 9 means maximum smoke. The result is in between 3 and 8 . Values of 7 and more indicate smoke emission beyond safe limit [7]. The range from 0 to 3 is acceptable and considered safe. Another thing to be noted is that excess air helps to produce cleaner combustion than in absence of excess air which can be seen from the table. As tabulated, it can be seen that coal emission is harmful even there is supply of excess air. Briquette with lime is far safer than briquette without lime in terms of emission as lime captures emission and it also acts as a binder during briquetting. In addition to this, lime also captures soot to some extent and also acts as a heat enhancer. 
138 Waste to Energy: An Assessment of Application of the Selective Fuel for Applications in Industries using .....

3.12 Flue Gas Emission Test

Table 4: Flue gas emission level

\begin{tabular}{|c|c|c|c|c|c|}
\hline S.No & Duration/description & $\begin{array}{c}\mathrm{CO}(\mathrm{ppm}) \\
\mathrm{V} / \mathrm{V}\end{array}$ & $\mathrm{SO}_{2}(\%)$ & NOx $(\mathrm{ppm})$ & $\begin{array}{c}\mathrm{CO}_{2}(\%) \\
\mathrm{V} / \mathrm{V}\end{array}$ \\
\hline 1 & Starting & 50 & 0 & 20 & 3 \\
\hline 2 & After 10 minutes & 20 & 0 & 10 & 1 \\
\hline 3 & After 20 minutes & 100 & negligible & 10 & 2 \\
\hline 4 & Average value & 56.66 & 0 & 13.33 & 2 \\
\hline
\end{tabular}

Source: NAST lab report, 2014

Table 5: National Ambient Air Quality Standards of Nepal, 2003

\begin{tabular}{|c|c|c|c|c|}
\hline Parameters & Units & Averaging time & WHO guideline & $\begin{array}{c}\text { Concentration in ambient } \\
\text { air, maximum }\end{array}$ \\
\hline \multirow{2}{*}{$\mathrm{CO}$} & $\mathrm{ppm}$ & 8 hours & \multirow{2}{*}{87.37} & 8.73 \\
\cline { 3 - 3 } & & 15 minutes & & 87.37 \\
\hline $\mathrm{SO}_{2}$ & $\mathrm{ppm}$ & Annual & \multirow{2}{*}{0.04} & 0.01 \\
\cline { 3 - 3 } & & 24 hours & & 0.02 \\
\hline $\mathrm{NO}_{2}$ & \multirow{2}{*}{$\mathrm{ppm}$} & Annual & \multirow{2}{*}{0.07} & 0.02 \\
\cline { 3 - 3 } & & 24 hours & & 0.04 \\
\hline
\end{tabular}

Source: Central Bureau of Statistics, 2011

The national ambient air quality standards of Nepal have been taken as emission standard. If the initial two tables are compared, it can be seen that $\mathrm{CO}$ emission from the briquette is within the safe limit (taking WHO guideline into account). The sulphur dioxide emission from the briquette is zero so the addition of lime has worked completely. But the results have shown that NOx emissions are not reduced and exceed the emission standard by far. So, separate calculations are to be done to capture NOx emissions. There is no $\mathrm{CO}_{2}$ emission standard to compare with the result. However, $\mathrm{CO}_{2}$ level is expected to decrease in briquette than in coal as the amount of coal decreases in the briquette.

\subsection{Economic Analysis}

The annual production using the RKJ II model having capacity $120-150 \mathrm{~kg} / \mathrm{h}$ is 255.36 tonnes. However, the full capacity cannot be achieved. So, plant capacity is assumed to be $75 \%$ for practical purpose. The contingency cost is taken to be 10 percent of investment cost as it is taken such in. The potential of uncertainty like malfunctioning of machines has also been taken into consideration. The cost of different component has been increased each year considering the inflation. The average inflation rate is around $8.36 \%$ as per the report of Nepal Rastra Bank during 
2014. The interest rate is assumed to be $10 \%$ as it is the common interest taken into account for renewable energy projects. The price of high quality coal varies from Rs 22/kg (coal from Assam) to Rs $25 / \mathrm{kg}$ (coal from Jharkhand) according to market survey. The owners of brick kilns are looking for a fuel that costs Rs 12 to 13 per kg. The breakeven price is NRs 15.19 as obtained from the iteration of IRR for which the IRR value is $10.02 \%$ that is greater than MARR which is $10 \%$ and the corresponding NPV in this case is NRs 1437.28. From study of slaughterhouse waste to biogas, with subsidy the net present value is NRs 629646.26 and IRR is $16.23 \%$. Without subsidy,the net present value is NRs 229646.26 and IRR is $12.6 \%$ [5]. In this study of selective fuel, the analysis period is 15 years. The life span of briquetting machine, shredder and grinder is 15 years whereas the life span of propeller is 6 months. Since most waste are compostable and recyclable, waste may not be available free. In this case, even the waste cost say Rs $5 / \mathrm{kg}$, the total price of the briquette is still less than that of coal. So, the briquette is cost-effective too as compared to coal. If the price is increased, the rate of return also gets increased. So, this type of project is financially sound. Hence the installation of small scale plant is economically feasible. The sensitivity analysis done to see change in NPV and IRR with respect to change in price of the briquette is shown in the following table and graphs.

Table 6: Sensitivity analysis of price of briquette on NPV and IRR

\begin{tabular}{|l|l|l|}
\hline Price $(\mathrm{NRs} / \mathrm{kg})$ & NPV $(\mathrm{NRs})$ & IRR $(\%)$ \\
\hline 5 & -24043287 & - \\
\hline 10 & -12249049.66 & - \\
\hline 15 & -454812.60 & 2.33 \\
\hline 20 & 11339424.45 & 137.85 \\
\hline 25 & 23133661.51 & 266.30 \\
\hline 30 & 34927898.57 & 394.70 \\
\hline
\end{tabular}

From the table it can be seen that low prices of fuel like NRs 5/kg and NRs 10/kg will not generate any return and the breakeven price lies between NRs $15 / \mathrm{kg}$ and NRs $20 / \mathrm{kg}$.

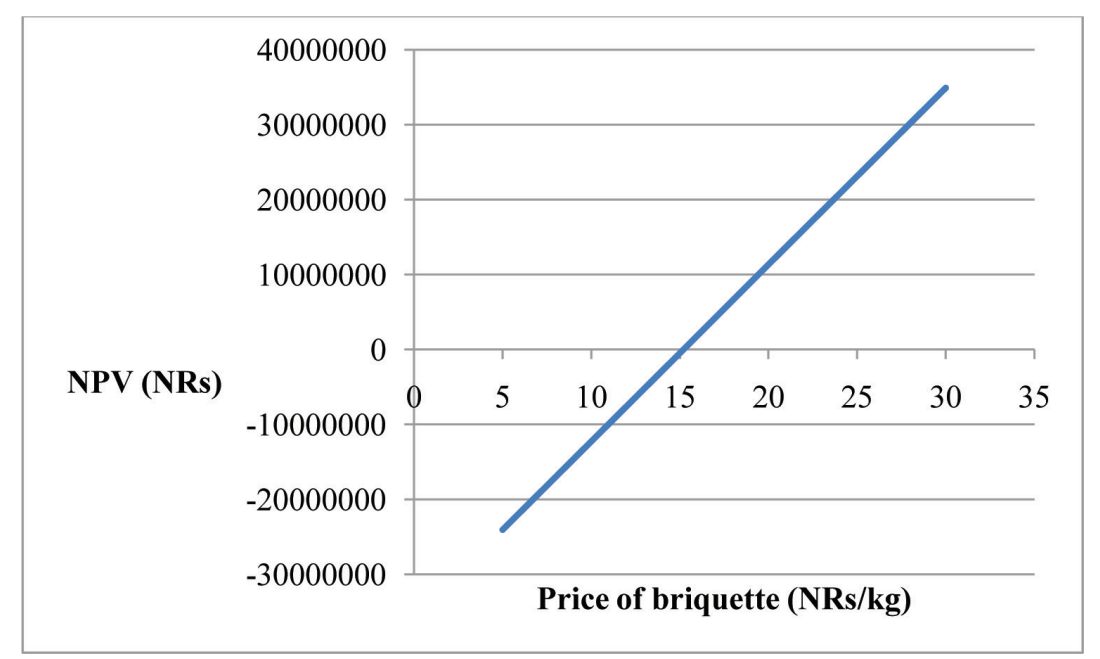

Fig 9: Effect of change in price of the briquette on NPV 
The slope of the graph of NPV vs price of fuel is very steep. Therefore, the effect of price of fuel on the NPV is very strong. The NPV is negative for any price equal to or below NRs $15 / \mathrm{kg}$ that means the price has to be made higher than that to make this type of project economically feasible. So, price around NRs 15 is the breakeven price. From the graph it can be said that the NPV increases with increase in price of the fuel.

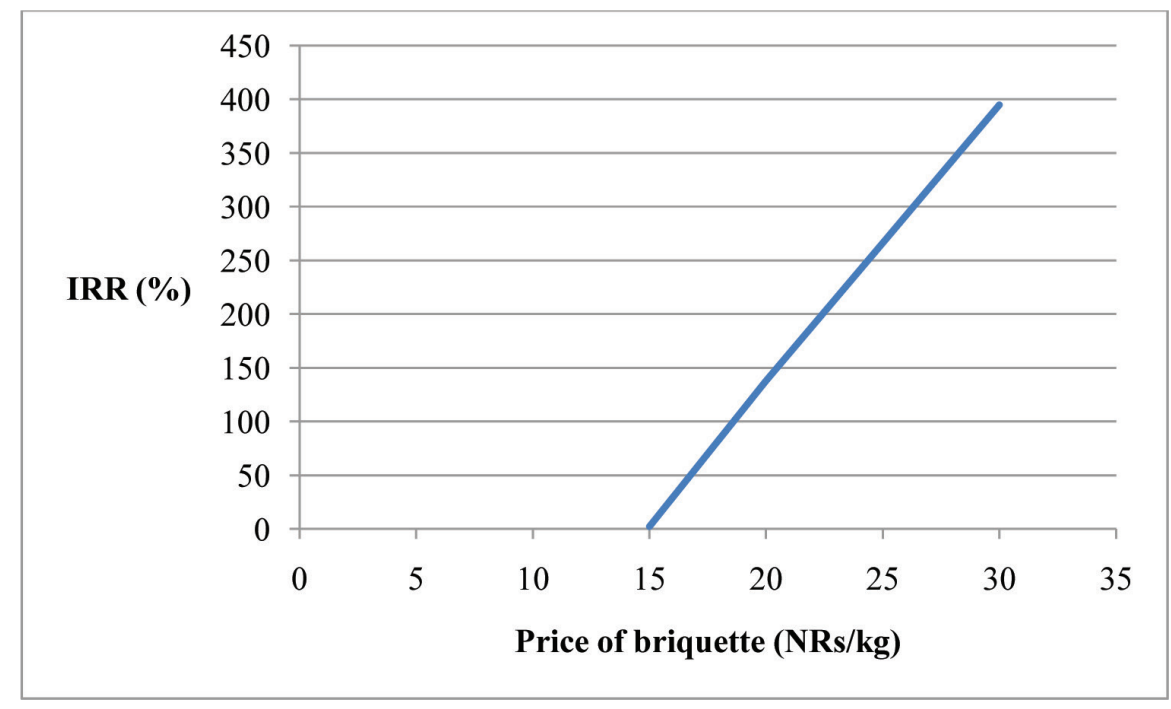

Fig 4.11: Effect of change in price of the briquette on IRR

There is regularity in the trend of the graph of price of fuel vs the IRR. IRR increases with increase in price of the fuel as well. Price should be greater than NRs 15/kg to get good rate of return.

\subsection{Scope of Energy Value of Municipal Solid Waste}

As per the data of MSW [15], the total amount of waste generated annually is 470025.1 tons when calculated. Their combine calorific value will be $3.36 * 10^{\wedge}(12) \mathrm{kcal}$ or $1.4^{*} 10^{\wedge} 7$ GJ. The average amount of consumption of coal in industrial is 7,293,800 GJ.

Similarly, the average amount of imported coal is 279980 tons whose calorific value is $2.005 *$ $10^{\wedge}(12) \mathrm{kcal}$ or $8394534 \mathrm{GJ}$. So it can be seen if MSW of all municipalities are considered, the energy value is more than that provided by coal, this is where we are losing an important source of energy. For a single VSBK (based on data from field visit to VSBK at Imadol), it requires 730 tons of coal annually. Say, for example if it uses the selective fuel from a single producer (considering very good production capacity), it can get 438 tons of SF for its operation and it now only requires 292 tons of coal. That means $60 \%$ of coal is replaced by SF or $39 \%$ of energy for the kiln is provided solely by MSW (considering plastic in it). The projects like these even benefits the waste management issue as the waste itself acts as a resource. WTE can reduce the transport of MSW to distant landfills and the associated emissions and fuel consumption [4]. According to 2069/70 budget of Kathmandu Metropoltan City (KMC), the annual spending on landfilling is Rs 7370230.68 [6]. So, a project like this can save such expenses.

KMC saving $=(7370230.68 /(398.94 * 365))=$ Rs 50.61 per ton of waste. 
Where 398.94 ton is the collected amount of waste by KMC that can provide energy as well and it doesn't include all the waste that is generated. U.S. data indicate a net emission reduction of 0.15 ton of carbon equivalent was achieved for every ton of MSW managed by WTE instead of being landfilled (with the national average methane recovery) in 2003 [3]. This opens a business opportunity for private sector as even the waste may cost some money, these projects are viable as long as cost of the briquette (Selective fuel) is less than that of the coal. So, those private sectors working in waste management can benefit from this type of project.

\section{Conclusion}

Most of the earlier researches have been done on low grade coal and plastic waste only. But this study has been done on high grade coal and municipal waste as a whole. The selective fuel was undergone proximate analysis, smoke index test, flue gas emission test and was also tested for its calorific value. The moisture content and ash content is found to be $8.69 \%$ and $11.21 \%$ respectively which is the acceptable range for VSBK. The fixed carbon content of the fuel is $28.03 \%$. The sulphur content of the coal is $6.4 \%$ which can be captured using $\mathrm{Ca}(\mathrm{OH})_{2}$. Addition of lime and presence of excess air help to control smoke during combustion. Flue gas emission test shows $\mathrm{CO}$ emission of $56.66 \mathrm{ppm}, \mathrm{CO}_{2}$ emission of $2 \%$ and no $\mathrm{SO}_{2}$ emission. The produced fuel briquette can be used for industrial applications for e.g. in brick kiln but suitable measure must be used to capture harmful emissions. All these conditions favors the application of the selective fuel. The addition of plastic waste seems to increase the calorific value of the fuel. The installation of small scale plant is sound in terms of technical details and is eco-friendly as this type of project is useful in reduction of harmful emissions. Further study could be carried out using waste samples from rural areas as well. Further study is to be done in plastic waste regarding dioxin and furan emissions which has not been done in this study due to lack of methods and equipments in Nepal. Ways to decrease volatile matter content of the fuel is to be found out. The energy invested in operating the waste to energy programs should be compared with the energy output from it. The economic analysis should be carried out for larger plants that can process 10 tonnes of waste per day which is more practical than small scale plants. This type of waste to energy conversion options not only act as waste management technique but also act as an alternative source of energy.

\section{References}

[1] Al-Salem SM, Lettieri P and Baeyens J (2010), The valorization of plastic solid waste (PSW) by primary to quaternary routes: from re-use to energy and chemicals. Progress in Energy \& Combustion Science: 103-129.

[2] Heejoon K, Singh RM and Tianji L (2006), Ecofuel- A blend of coal with plastic. Journal of World Review of Science, Technology and Sustainable development: 49-57.

[3] Hefa C and $\mathrm{Hu}$ Y (2010), Municipal Solid Waste as renewable source of energy: Current and future practices in China. Bioresource Technology 101: 3816-3814.

[4] Kaplan PO, DeCarolis J and Thorneloe S (2009), Is it Better to Burn or Bury Waste for Clean Electricity Generation. Environ. Sci. Technol. 43: 1711-1717.

[5] KC P (2015), Production of Biogas from Slaughterhouse Waste in Lalitpur Submetropolitan City. Department of Mechanical Engineering, Pulchowk Campus, Institute of Engineering, Nepal

[6] KMC (2013), Budget of 2070/71. Kathmandu Metropolitan city, Kathmandu, Nepal 
142 Waste to Energy: An Assessment of Application of the Selective Fuel for Applications in Industries using .....

[7] Krizan P, Matus M, Soos L, Kers J, Peetsalu P, Kask U, Menind A (2011) Briquetting of Municipal Solid Waste by Different Technologies in order to evaluate its Quality and Properties. Biosystem Engineering: 115-123.

[8] Maity S, Maithel S and Muller H (2010), Coal quality field testing guidelines for firing VSBK with external coal. Vertical Shaft Brick Kiln Project., Kathmandu, Nepal.

[9] Masters GM (2006), Introduction to Environmental Engineering and Science. Prentice Hall of India Pvt. Ltd., New Delhi, India.

[10] Patumsawad P and Cliffe KR (2002), Experimental Study on Fluidised Bed Combustion of High Moisture Municipal Solid Waste. Energy Convers. Manage. 43: 2329-2340.

[11] Rajaure N (2011), Final Report of ARF. Kathmandu, Nepal.

[12] Shah AP (2010), Techno-economic Assessment of Waste to Energy Conversion: Anaerobic Digestion for Solid Waste Management in Kathmandu Metropolitan City. Department of Mechanical Engineering, Institute of Engineering, Tribhuvan University, Nepal.

[13] Shrestha A (2011), Energy Recovery from Municipal Solid Waste by Briquetting Process:Evaluation of Physical and Combustion properties of the Fuel. Department of Environment Science, Tribhuvan University, Nepal.

[14] Singh RM, Kim HJ, Kamide M and Sharma T (2009), Biobriquette- an alternative fuel for sustainable development. Nepal Journal of Science and technology: 121-127.

[15] SWMTSC (2012), Preparation of Solid Waste Management Strategic Plan and Action Plan for 15 municipalities Draft Final Report. Solid Waste Management and Technical Support Center., Lalitpur, Nepal. 